\title{
New species of Sphagnum from the Philippines with remarkable morphological characters
}

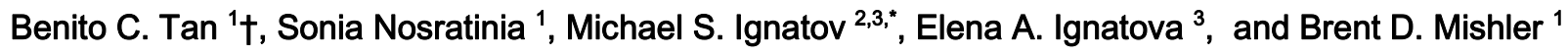

\begin{abstract}
Sphagnum apopenneysii B.C. Tan, Ignatov, Ignatova, \& B. Mishler is described as a species new to science. It was found submerged in a high mountain lake, at $2385 \mathrm{~m}$ elev. on Mt. Apo on Mindanao island in the Philippines. The new species is peculiar in its poor expression of leaf cell dimorphism. Cells in the upper half of the branch leaves are all identical, linear-vermicular, and all have chloroplasts and nuclei. In the mid-leaf, a moderate differentiation in shape appears with larger cells, approaching in shape to hyalocysts, yet still containing chlorophyll. Only near the base of the branch leaves is a pattern common to most Sphagnum species observed, including inflated hyalocysts with fibrils, albeit without any pores. Collections from deeper water have long lanceolate leaves, while plants from shallower water have stem leaves that are ovate-triangular, similar to those in many species of Sphagnum in section Cuspidata. Both nuclear and plastid DNA sequence data support the placement of this new moss in section Cuspidata.
\end{abstract}

KEYWORDS: Sphagnum apopenneysii, Sphagnum sect. Cuspidata, chlorocyst, hyalocyst

\section{INTRODUCTION}

A 2014 collecting trip to the highest peak in the Philippine archipelago, Mt. Apo (2954 m) on Mindanao island, organized jointly by Central Mindanao University and the California Academy of Sciences, yielded a collection of an enigmatic Sphagnum with remarkable morphological characteristics. It was found growing submerged in a high elevation crater lake, Lake Jordan $\left(6.976^{\circ} \mathrm{N}, 125.260^{\circ} \mathrm{E}, 2385 \mathrm{~m}\right)$, on the southwest slope near the summit of Mt. Apo (Fig. 1).

Sphagnum in the Philippines is moderately rich in diversity with 7 species, none of which is a local endemic (Tan \& Iwatsuki 1991). However, two species, namely S. luzonense Warnst. and $S$. robinsonii Warnst., have a restricted and disjunctive range between Indochina (Thailand and Vietnam) and Luzon Island in northern Philippines (Eddy 1977, 1988).

${ }^{1}$ University and Jepson Herbaria, 1001 Valley Life Sciences Building, University of California, Berkeley, CA 94720 USA

${ }^{2}$ Main Botanical Garden, Russian Academy of Science, Botanicheskaya 4, Moscow 127276 Russia

${ }^{3}$ Biological Faculty, Moscow State University, Moscow 119234 Russia

Corresponding author: misha_ignatov@list.ru

Date Submitted: 17 November 2017

Date Accepted: 02 April 2018
A new species of Sphagnum from the southernmost part of the country is therefore a remarkable discovery.

Compared to the Sphagnum species known worldwide (Nyholm 1969; Eddy 1977; Smith 1980; Crum \& Anderson 1981; Sharp et al. 1994; Li \& He 1999; Seppelt 2006), and given the authors' experience in regional floristic explorations in Europe, North America and Asia, including the Philippines, the newly discovered Sphagnum has the distinctive morphological characters of having a weak to no differentiation of stem and branch leaves, mostly efibrillose leaf cells, absence of pores on the leaf cells, and little or no differentiation of chlorocysts and hyalocysts in leaves, especially the branch leaves. The first impression was that this moss represented a species in the family Amblystegiaceae, because of the aquatic habitat and the narrowly lanceolate leaves with smooth, elongate to vermicular cells. Branches in plants from deep water appeared mostly single, not in fascicles, but soon the presence of fascicles was noticed, and the short stem leaves with few fibrillose hyalocysts along with the stem anatomy, led us to identify these plants as a Sphagnum, but of an unknown species.

In order to determine the taxonomic placement of the newly discovered moss, we examined its morphology and anatomy, and assembled a set of molecular characters from its nuclear, chloroplast, and mitochondrial genomes. 

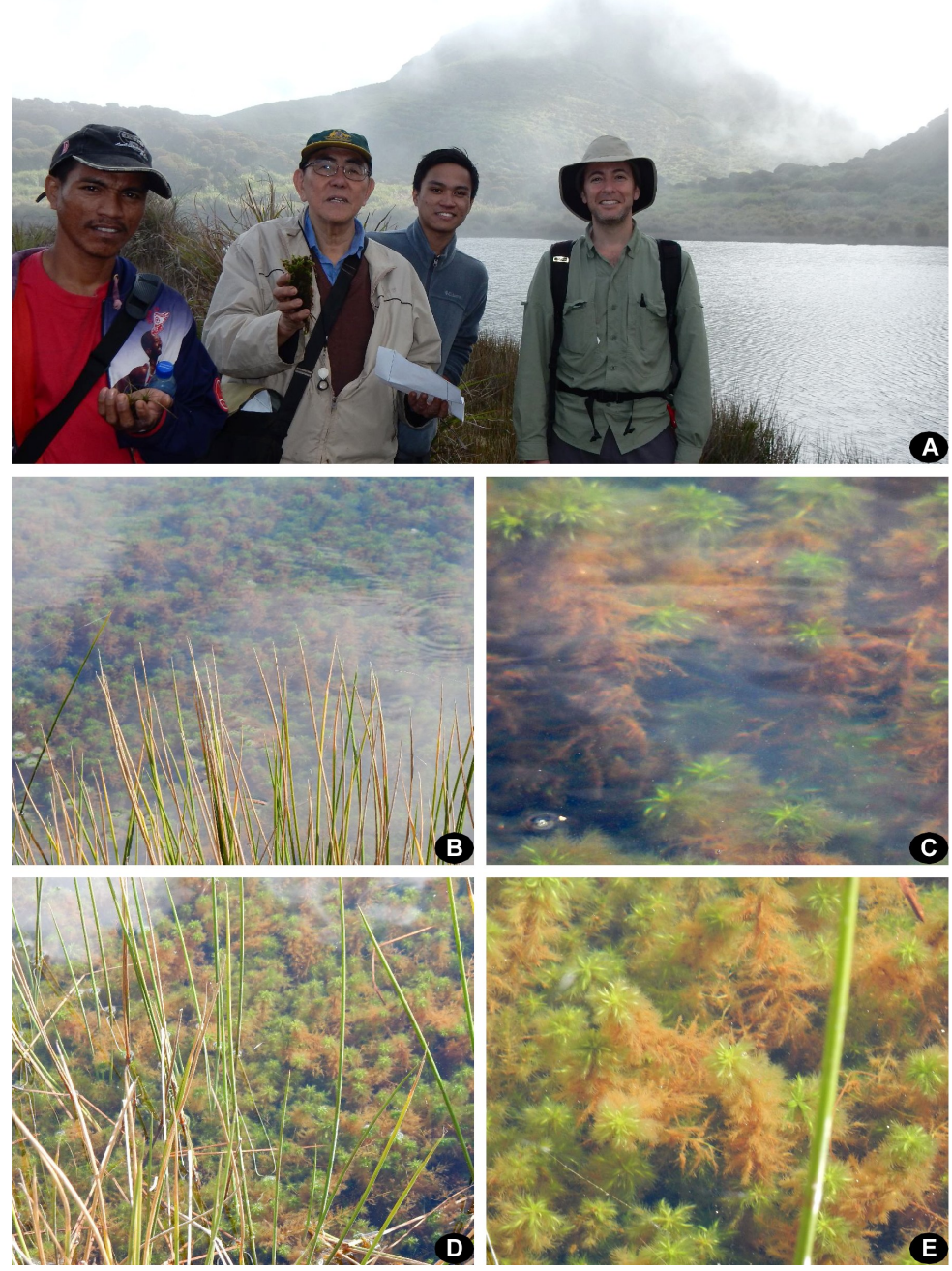

Figure 1. Sphagnum apopenneysii habitat. A: Jordan Lake; from left to right in the picture are local trail guide; Benito Tan, Jeffrey Mancera and Darin Penneys; just collected Sphagnum is in hands of Benito. B and C: deeper water part of population (to at least $2 \mathrm{~m}$ from shore, and to $40 \mathrm{~cm}$ deep); D and $E$ : part of population closer to lake shore, Sphagnum is floating mostly just below water surface. The type collection was made at about a meter into the lake, and at a depth of ca. $20 \mathrm{~cm}$. Photos provided by Darin Penneys.

\section{MATERIALS AND METHODS}

Morphological study involved mostly standard light microscopy, with an additional observation with fluorescence made in order to check the distribution of nuclei. Herbarium material was studied in slides with DAPI and berberine staining, which visualize specifically DNA under $\lambda=405 \mathrm{~nm}$ and cell walls under $\lambda=473 \mathrm{~nm}$ correspondingly. Observations were conducted with an FV-Olympus 1000 Laser confocal scanning microscope. Some images were supplemented with pseudo-transmitted images, for example those of stem hyalodermis, where fluorescence was too weak.

Taxon selection for DNA sequence analyses comprised 55 representatives of the genus Sphagnum, plus three representatives of the closely related genera Eosphagnum and Flatbergium as outgroups (Table 1). To ensure the congruence of the datasets, the sphagna that have been shown to combine the nuclear sequences of one section with the chloroplast sequences of another (Shaw 2000, Shaw and Goffinet 2000) were not included in this study. The intrasubgeneric allopolyploids were not excluded however, because none was revealed to be closely related to the newly discovered moss, and previous studies (Shaw and Goffinet 2000, Soltis et al. 2008) have shown that inclusion or removal of sequences from such hybrids in total evidence analyses does not have a substantial effect on the inferred relationships among the non-hybrid taxa.

Nucleotide sequences for one nuclear (ITS1+ $5.8 S+$ ITS2), two plastid (rps4- trnS ${ }^{G G A}$ and $t r n \mathrm{~L}^{\mathrm{UAA}}-\mathrm{trnF}^{G A A}$ intergenic spacers), and one mitochondrial (nad5) genomic regions were obtained from GenBank for all taxa except the newly discovered moss. The choice of markers was based on the Sphagnum sequences already available in GenBank. The names and GenBank accession numbers for the downloaded taxa are provided in Table 1. Sequences of the type specimen of the newly discovered moss (Holotype: Philippines, Mindanao Island, Mt. Apo, Lake Jordan, UC) were generated according to the protocols described in Nosratinia et al. (2011) using the same primer sequences. The amplification and sequencing of the chloroplast $t r n \mathrm{~L}-t r n \mathrm{~F}$ region was done using the $\mathrm{TabC}$ and TabF primers (Taberlet et al. 1991) and the rps4 thermocycling profile. The ITS region was amplified and sequenced using primers ITS leu1 (Urbatsch et al. 2000) and ITS4 (White et al. 1990) under the following cycling conditions: $5 \mathrm{~min}$ at $94^{\circ} \mathrm{C}$, then 40 cycles of $1 \mathrm{~min}$ at $94^{\circ} \mathrm{C}, 1 \mathrm{~min}$ at $48^{\circ} \mathrm{C}$, and $45\left(+4 \mathrm{~s} /\right.$ cycle) at $72^{\circ} \mathrm{C}$, followed by a final extension of $5 \mathrm{~min}$ at $72^{\circ} \mathrm{C}$. Cycle sequencing reactions were carried out at the UC Berkeley DNA Sequencing Facility. Forward and reverse chromatogram sequences were manually reviewed, edited, and assembled using Geneious version 6.1.8 (http:// www.geneious.com, Kearse et al. 2012) and Aliview (Larsson 2014). The combined aligned sequence matrix contained 3673 alignment positions. Three dataset partitions (cpDNA, nDNA, and mtDNA) were analyzed, separately and combined, under the maximum likelihood (ML) criterion through the CIPRES web-portal with RAxML ver. 7.2.8 (Stamatakis 2006, Stamatakis et al. 2008) using 1000 bootstraps and the GTR+CAT model for both bootstrapping and tree inference. Upon discovery of the placement of the new Sphagnum within the section Cuspidata, the initial sampling was supplemented by downloading the appropriate sequences for a representative of every Cuspidata species available in GenBank. Due to both morphological and molecular similarities observed between the newly 
Philippine Journal of Systematic Biology | Tan, B.C. et al: New species of Sphagnum from the Philippines

Table 1. Taxon sampling and GenBank accession numbers for the DNA sequences used in this study.

\begin{tabular}{|c|c|c|c|c|}
\hline \multirow[t]{2}{*}{ Taxon } & \multicolumn{4}{|c|}{ GenBank Accession Numbers } \\
\hline & rps4 & $t r n \mathrm{~L}-\mathrm{F}$ & nad5 & ITS \\
\hline Eosphagnum rigescens & AY309722 & KU725456 & KU725510 & AY298521 \\
\hline Flatbergium novo-caledoniae & KU725454 & KU725454 & KU725492 & \\
\hline Flatbergium sericeum & KU725458 & KU725458 & KU725489 & AY298644 \\
\hline Sphagnum angustifolium & KU725442 & KU725442 & KU725478 & AF193686 \\
\hline Sphagnum annulatum & & AY298007 & & AY298373 \\
\hline Sphagnum aongstroemii & KU725451 & KU725451 & KU725495 & AF193748 \\
\hline Sphagnum apopenneysii & MG604232 & MG604233 & MG604234 & MG604231 \\
\hline Sphagnum austinii & KU725462 & KU725462 & KU725493 & AY298383 \\
\hline Sphagnum balticum & KU725468 & KU725468 & KU725497 & AF193707 \\
\hline Sphagnum bartlettianum & KU725444 & KU725444 & KU725502 & AF193727 \\
\hline Sphagnum boyacanum & & AY298029 & & AY298396 \\
\hline Sphagnum capillifolium & KU725443 & KU725443 & KU725488 & AY298400 \\
\hline Sphagnum centrale & KU725466 & KU725466 & KU725487 & AY298414 \\
\hline Sphagnum compactum & KU725453 & KU725453 & KU725483 & AY298419 \\
\hline Sphagnum curvatulum & & AY298054 & & AY298423 \\
\hline Sphagnum cuspidatulum & & AY298058 & & AY298429 \\
\hline Sphagnum cuspidatum 1 Philippines & & AY298063 & & AY298432 \\
\hline Sphagnum cuspidatum 2 Japan & & AY298055 & & AY298424 \\
\hline Sphagnum cuspidatum 3 Australia & & JQ712988 & & \\
\hline Sphagnum cuspidatum 4 U.S.A. & KU725471 & KU725471 & KU725480 & \\
\hline Sphagnum cuspidatum 5 U.S.A. & AY309718 & AF192633 & AY309560 & AF193677 \\
\hline Sphagnum fallax & KU725463 & KU725463 & KU725501 & AF193725 \\
\hline Sphagnum fitzgeraldii & & AY298092 & & AF193751 \\
\hline Sphagnum flexuosum & & AY298097 & & AY298464 \\
\hline Sphagnum fuscum & KU725465 & KU725465 & KU725499 & AY309503 \\
\hline Sphagnum girgensohnii & KU725439 & KU725439 & KU725476 & AY298477 \\
\hline Sphagnum jensenii & & AF192602 & & AF193688 \\
\hline Sphagnum laegaardii & & & & AY361014 \\
\hline Sphagnum lescurii & KU725457 & KU725457 & KU725486 & AF193667 \\
\hline Sphagnum lindbergii & & AY298157 & & AY298525 \\
\hline Sphagnum magellanicum & KU725440 & KU725440 & KU725498 & AY298531 \\
\hline Sphagnum majus & & AY298171 & & AY298538 \\
\hline Sphagnum obtusum & KU725445 & KU725445 & KU725500 & AY298565 \\
\hline Sphagnum orientale & KU725447 & KU725447 & KU725494 & AF193717 \\
\hline Sphagnum pacificum & & AY298203 & & AY298570 \\
\hline Sphagnum palustre & KU726621 & KU726621 & KC784957 & AY298572 \\
\hline
\end{tabular}


Philippine Journal of Systematic Biology | Tan, B.C. et al: New species of Sphagnum from the Philippines

\begin{tabular}{lllll}
\hline Sphagnum papillosum & KU725474 & KU725474 & KU725511 & AY298574 \\
Sphagnum portoricense & KU725469 & KU725469 & KU725509 & AF193705 \\
Sphagnum pulchricoma & & AY298222 & & AY298589 \\
Sphagnum pulchrum & AY309726 & AY298224 & AY309568 & AY298591 \\
Sphagnum pylaesii & KU725461 & KU725461 & KU725508 & AY298593 \\
Sphagnum recurvum & KU725467 & KU725467 & KU725504 & AY298611 \\
Sphagnum riparium & KU725448 & KU725448 & KU725479 & AY298614 \\
Sphagnum rubellum & KU725473 & KU725473 & KU725484 & AY298624 \\
Sphagnum rubiginosum & KU725449 & KU725449 & KU725477 & AF193742 \\
Sphagnum rubroflexuosum & & AY298259 & & AY298625 \\
Sphagnum sancto-josephense & & AF192570 & & AF193684 \\
Sphagnum squarrosum & KU725464 & KU725464 & KU725506 & AY298651 \\
Sphagnum strictum & KU725450 & KU725450 & KU725490 & AF193714 \\
Sphagnum subnitens & KU725472 & KU725472 & KU725496 & AY298667 \\
Sphagnum tenellum & & AY298336 & & AF193746 \\
Sphagnum teres & KU725438 & KU725438 & KU725491 & AF193720 \\
Sphagnum torreyanum & KU725459 & KU725459 & KU725505 & AY298722 \\
Sphagnum troendelagicum & & & & AF193676 \\
Sphagnum viride & & AF192582 & & AF193710 \\
Sphagnum wulfianum & & AF192615 & & AY298710 \\
\hline
\end{tabular}

discovered moss and $S$. cuspidatum Ehrh. ex Hoffm., corresponding genetic markers for all available representatives of $\mathcal{S}$. cuspidatum in GenBank were included in the final sampling and analyses.

\section{RESULTS}

Very poor differentiation of laminal cells is an outstanding character of the newly discovered Sphagnum (Figs. 2-5). Distal laminal cells totally lack any differentiation: cells do not differ in shape, all possess chloroplast and nuclei, as can be revealed from the DAPI staining of herbarium specimens (Fig. $5 B$ ) with subsequent study with fluorescence microscopy, with laser $405 \mathrm{~nm}$. In the leaf middle some differentiation appears (Figs. 5C and 5D), but still with some red color of chlorophyll fluorescence seen in larger cells (underdeveloped hyalocysts). Closer to the leaf base, a few hyalocysts with fibrils occur in many, albeit not all leaves (Figs. 2E, 4I, 5E, L). Chlorocysts among these fibrillose hyalocysts do not form a regular net as in most species of Sphagnum, but chlorocyst ends adjoin at a certain distance to another chlorocyst cell (Figs. 5C-F), forming a pattern also seen in Flatbergium.
Separate phylogenetic reconstructions resulting from the nuclear and plastid data partitions (not shown) yielded similar trees and bootstrap support values and both placed the newly discovered Sphagnum in Sect. Cuspidata. The mitochondrial molecular data alone was unable to resolve many interrelationships within the genus but was included in the combined analyses. The 4-marker concatenated tree, rooted with sequences from the related Sphagnopsida genera, Eosphagnum and Flatbergium, revealed clades corresponding to the currently recognized subgenera Acutifolia, Cuspidata, Sphagnum, Subsecunda and Rigida with bootstrap support of $84-100 \%$ (Fig. 6). The newly discovered moss was placed in a clade with $S$. cuspidatum, $S$. laegaardii H.A. Crum, $S$. curvatulum H.A. Crum, $S$. boyacanum H.A. Crum, S. fitzgeraldii Renauld, and $S$. viride Flatberg with the bootstrap support value of $84 \%$.

A unique 12 base-pair long insertion event in the noncoding region of the rps4 marker with clearly defined alignment borders was observed in the new species that has not been observed in any other Sphagnum species or the outgroups (Fig. 7). The detected insertion was verified by sequencing the same marker for two additional samplings of the type specimen. 
Philippine Journal of Systematic Biology | Tan, B.C. et al: New species of Sphagnum from the Philippines
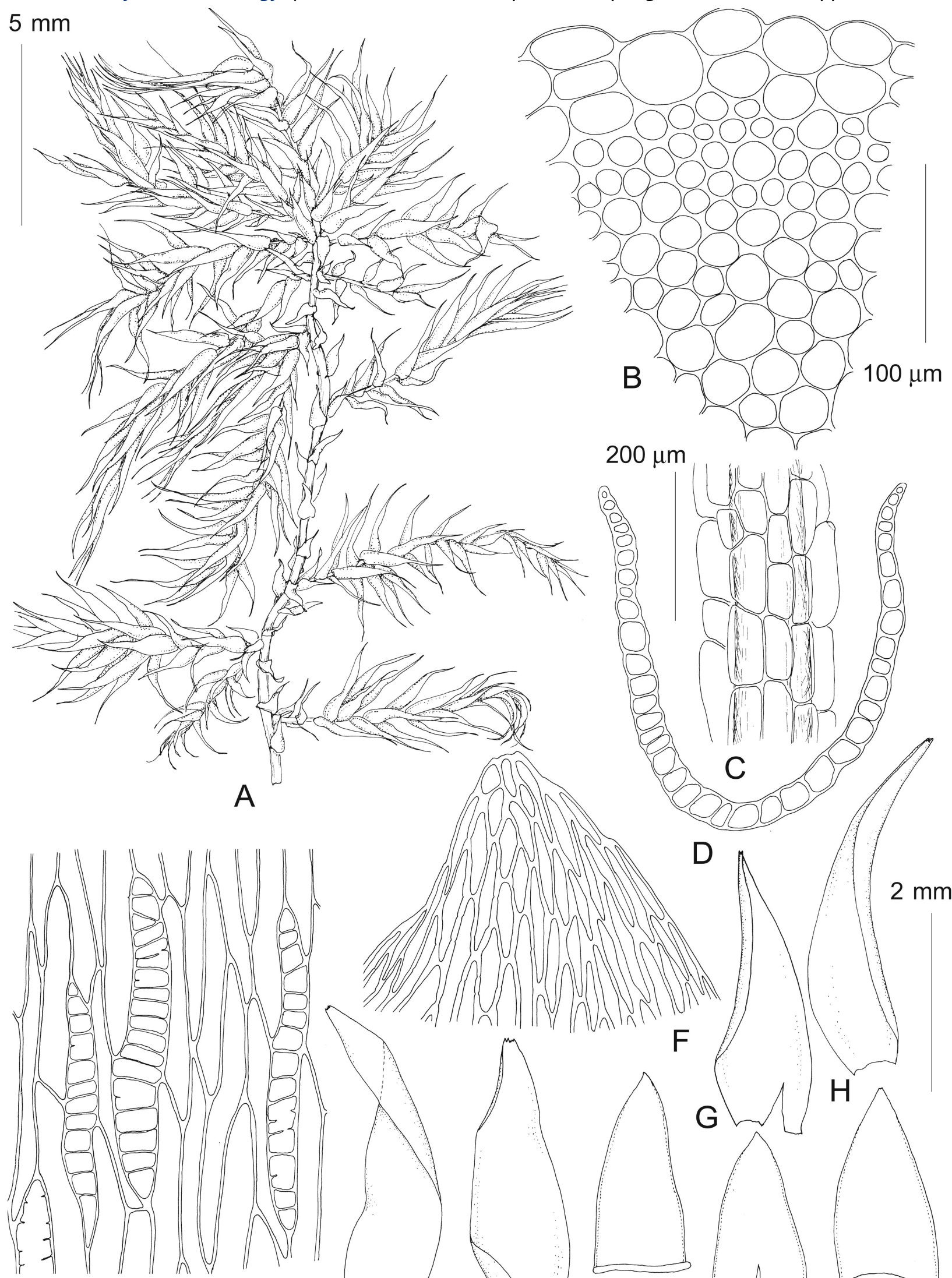

$\mathrm{E}$
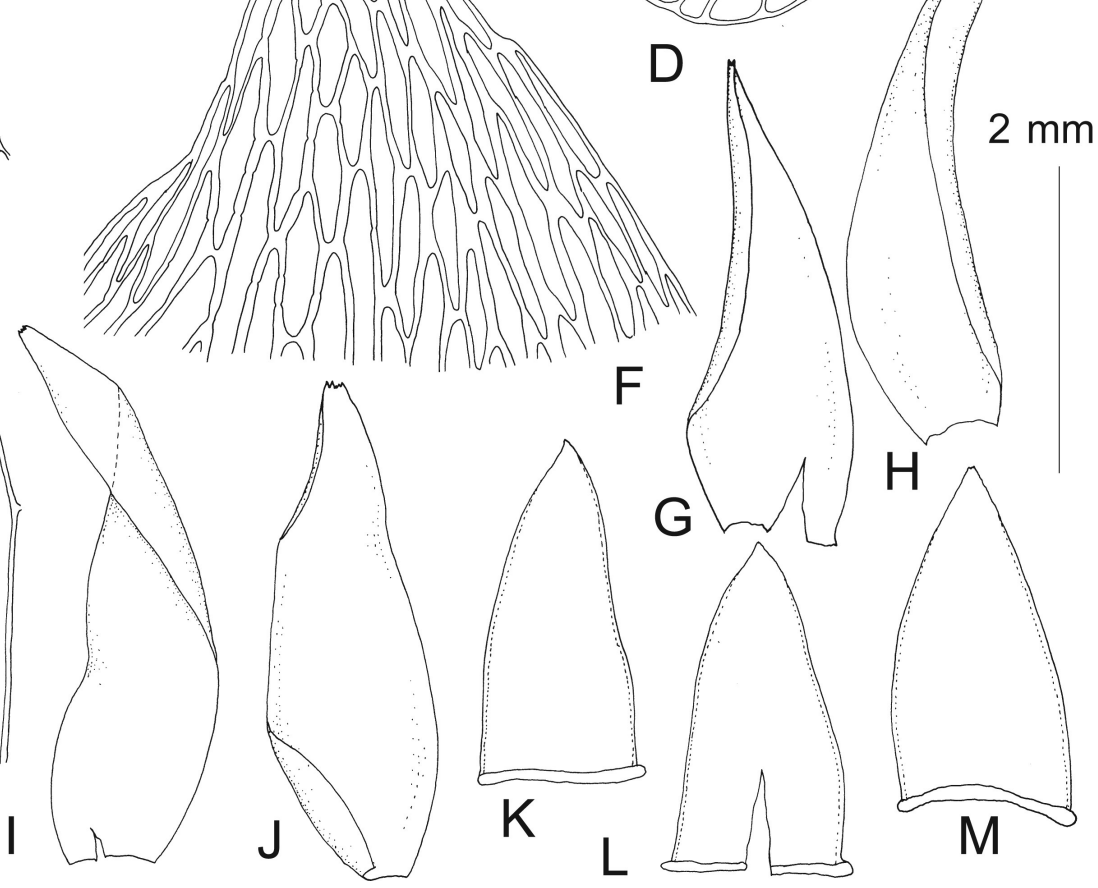

Figure 2. Sphagnum apopenneysii (from moderately submerged plants of isotype: Tan \& Penneys 2014-200, MW). A: habit, from dry herbarium specimen; B: stem transverse section; C: part of branch showing retort cells; D: branch leaf transverse section; E: cells of proximal part of stem leaf; F: cells in distal part of stem leaf; G-J: branch leaves; K-M: stem leaves. A: $5 \mathrm{~mm}$; G-M: $2 \mathrm{~mm}$; C: $200 \mu \mathrm{m}$; B, D-F: $100 \mu \mathrm{m}$. 


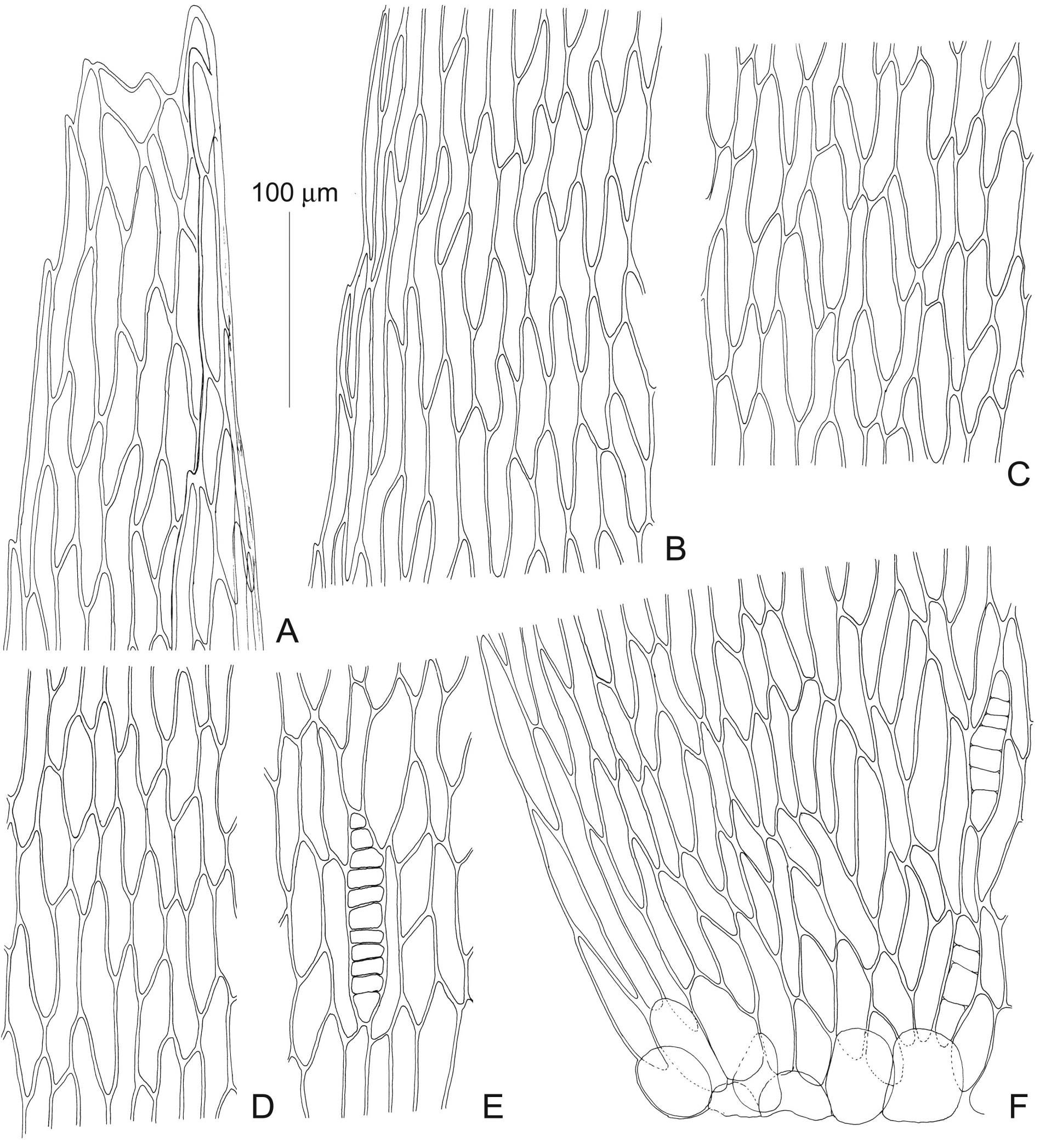

Figure 3. Sphagnum apopenneysii (from branch leaves of moderately submerged plants of isotype: Tan \& Penneys 2014-200, MW). A: apical cells; B: marginal cells at leaf middle; C: medial cells from ventral view; D: medial cells from dorsal view; E-F: cells of proximal part of branch leaf. Scale bars: A-F $100 \mu \mathrm{m}$. 
Philippine Journal of Systematic Biology | Tan, B.C. et al: New species of Sphagnum from the Philippines
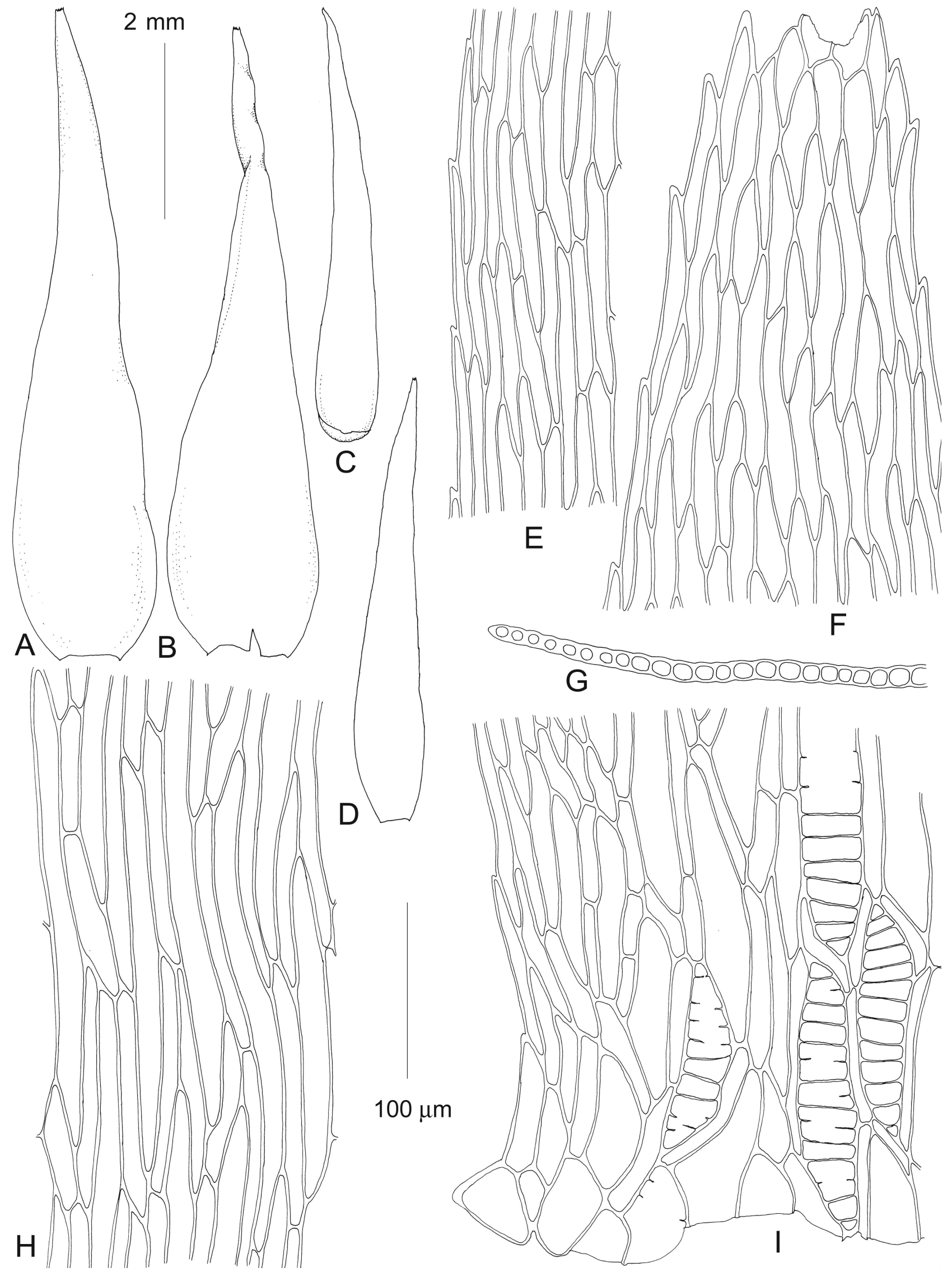

Figure 4. Sphagnum apopenneysii (from deeply submerged plants of isotype: Tan \& Penneys 2014-200, MW). A-B: stem leaves; C-D: branch leaves; E: marginal cells at middle part of branch leaf; F: cells of stem leaf apical part; G: stem leaf transverse section; $\mathrm{H}$ : cells at distal part of stem leaf, concave surface; I: basal cells of stem leaf. Scale bars: A-D: $2 \mathrm{~mm}, \mathrm{E}-\mathrm{I}: 100 \mu \mathrm{m}$. 
Philippine Journal of Systematic Biology | Tan, B.C. et al: New species of Sphagnum from the Philippines
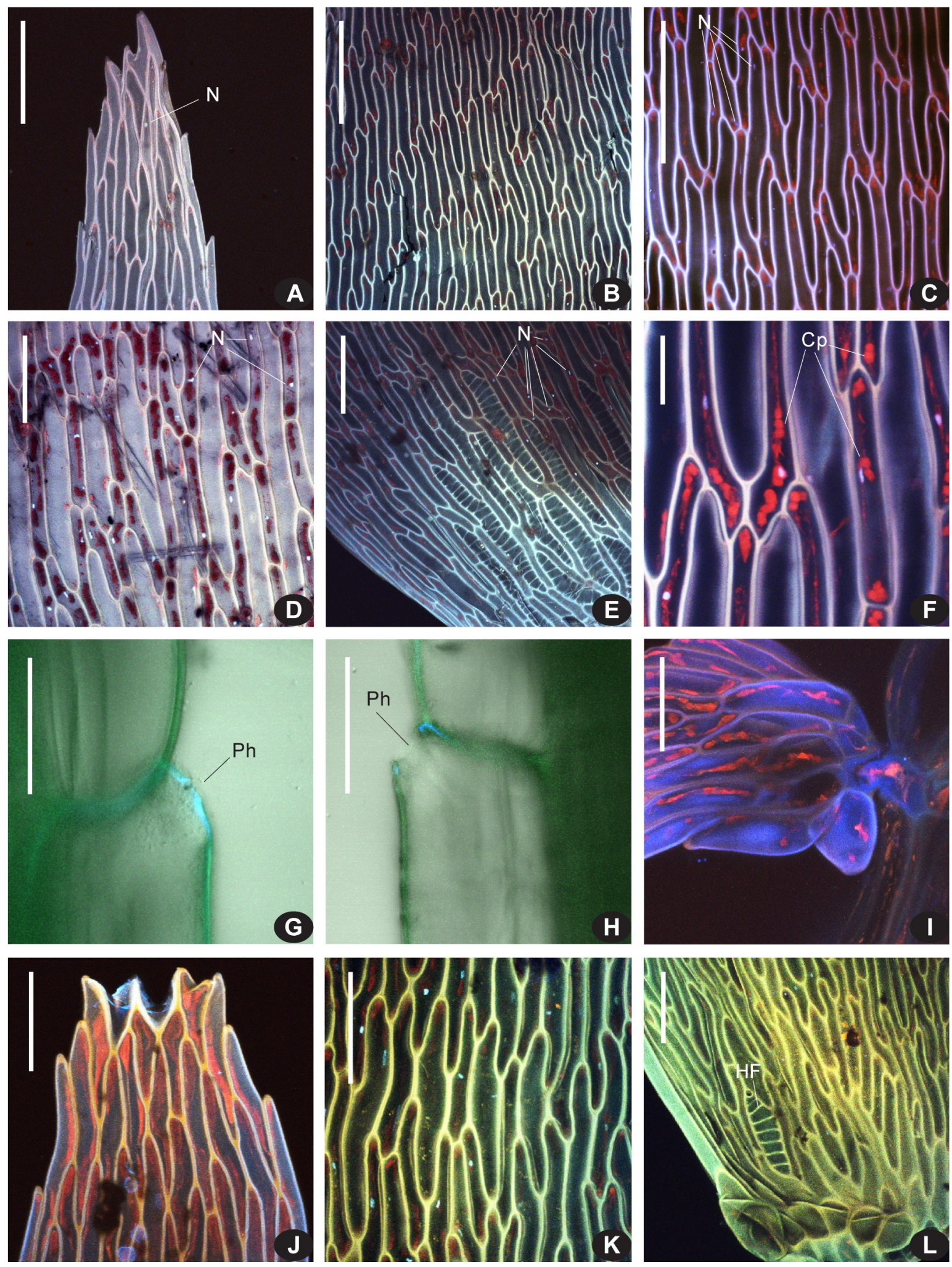

Figure 5. Sphagnum apopenneysii (A-I: from moderately and J-L: from deeply submerged plants of the isotype, Tan \& Penneys 2014-200, MW). A, J: apical part of branch leaves; B: distal part of branch leaf; C, K: medial part of branch leaves; D: medial to proximal part of branch leaf; E, L: basal part of branch leaves; F: medial part of stem leaf; G, H: hyalodermis cells with apical pores, fully opened $(H)$ or with only a small perforation $(G)$; I - branch leaf corner with tooth-like "auricle" at its base (cf. Fig. 4). A combination of DAPI and berberine staining and autofluorescence in fluorescence under combined $\lambda=405 \mathrm{~nm}+\lambda=473 \mathrm{~nm}$, showing nuclei (bright light blue) and chlorophyll (red), which outlines chloroplasts as a more or less regular elliptic bodies or otherwise showing lack of any structure of putatively severely decomposed plastids. Abbreviations $\mathrm{Cp}$ : chloroplasts; HF: hyalocysts with fibrils at leaf bases; N: nuclei; Ph: pore in stem hyalodermis cell walls. Scale bars: A-C, E: $100 \mu \mathrm{m}, \mathrm{D}, \mathrm{G}-\mathrm{L}: 50 \mu \mathrm{m} ; \mathrm{F}: 20 \mu \mathrm{m}$. 


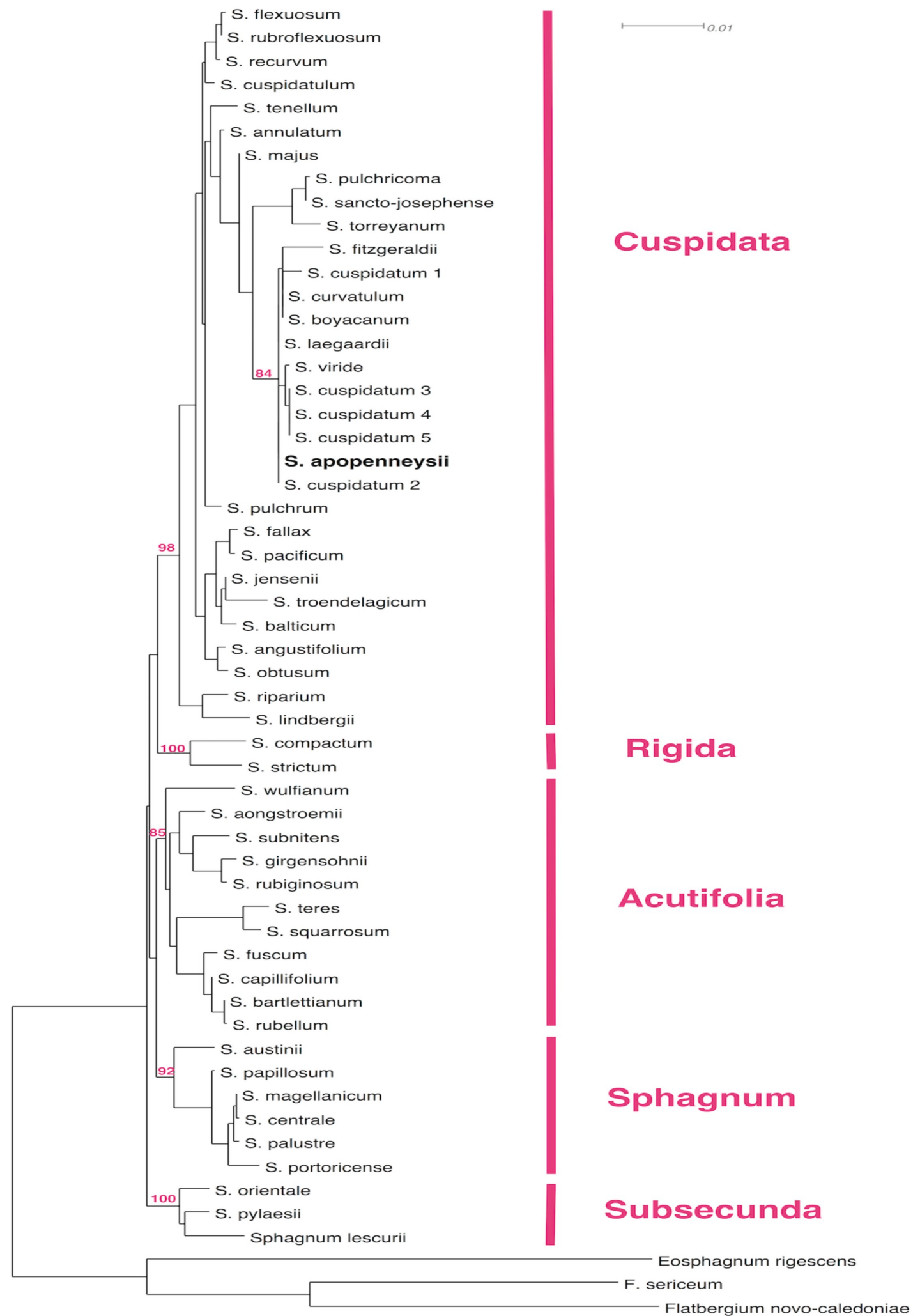

Figure 6. The most likely tree from the maximum-likelihood analysis of a combined 4-locus (rps4-trnS, trnL-F, nad5 and ITS) dataset. 


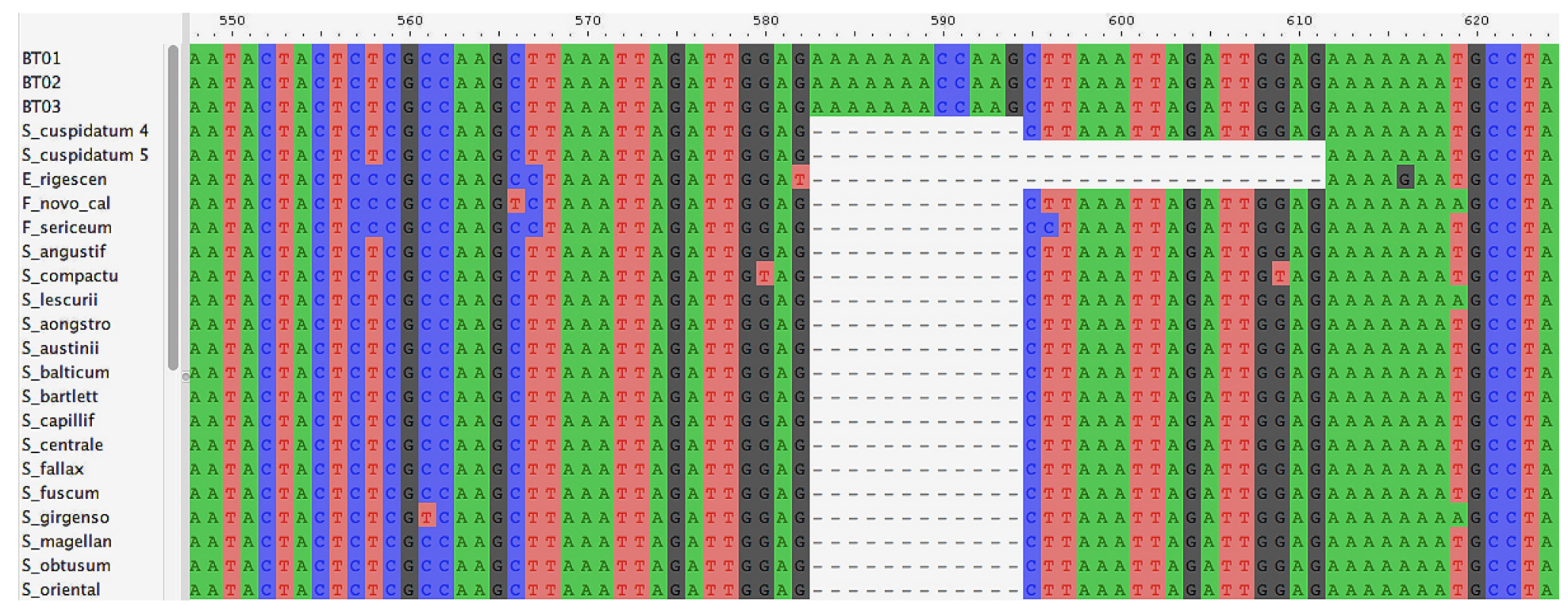

Figure 7. A unique insertion event in the noncoding region of the rps 4 marker in three sampling of the type specimen of Sphagnum apopenneysii with with genomic identifiers BT01, BT02 and BT03. It was originally noted that the population could include three species, but the three corresponding extractions were found to be identical for all 4 markers.

\section{DISCUSSION}

The distinct status of the plants from Mt. Apo is supported by the combination of habit, morphology, and molecular data examined in this study. It is different from Flatbergium is sericeum, one of a few other Sphagnopsida lacking fibrils, in having them in a few cells near the leaf base. Despite the obvious lack of any affinity to Flatbergium, the similarity in cell pattern is interesting, as it may indicate a possible correlation between this anomalous areolation and lack of fibrils. This correlation is worth future developmental studies.

Possible relationships with South American S. ehyalinum A.J. Shaw \& Goffinet, another Sphagnum with poorly differentiated hyalocysts and chlorocysts in branch leaves, is not supported, as $S$. ehyalinum's chloroplast data places it in section Subsecunda (Shaw and Goffinet 2000), while both chloroplast and nuclear data clearly place the newly discovered Sphagnum in section Cuspidata.

Sphagnum ehyalinum has recently been synonymized with $S$. falcatulum Besch. by Karlin et al. (2013) based on molecular evidence. There are two other cases where Sphagnum falcatulum was found with the extremely poorly developed leaf cell dimorphism. One was initially described as Drepanocladus fontinaliopsis var. flaccidus K.W. Allison (Allison, 1963) from New Zealand and later synonymized with S. falcatulum by Ochyra \& Bartlett (1986). Another was $S$. serrulatum Warnst. (Warnstorf, 1893), described from Tasmania, which was synonymized with $S$. falcatulum by Willis (1953), Seppelt (2006), and Karlin \& Robinson (2017) based on morphology.
In the absence of molecular evidence, the specimen from the Philippines might be referred to $\mathcal{S}$. falcatulum as well. However the organellar sequences indicate affinity with $S$. cuspidatum instead. A close relationship to the latter species is also suggested by the ovate-triangular stem leaves in plants that occur in more shallow places. However the poor differentiation of chlorocysts and hyalocysts in leaves and mostly efibrillose leaf cells without pores is a unique combination of characters in the new species.

The circumscription of $S$. cuspidatum has long been a matter of uncertainty (e.g. Griffin 1981, Hanssen et al. 2000), and its monophyly has no support from our sequence data (Fig. 6) or the indel data (Fig. 7). The worldwide analysis of $S$. cuspidatum based on microsatellites by Karlin et al. (2011) revealed a complicated genetic structure within the species, with plants from Australia, the Philippines, Colombia, and Equatorial Guinea differentiated from Northern Hemisphere populations.

Based on the limited number of loci available for this study, the newly discovered moss appears equally related to $S$. cuspidatum, S. laegaardii, S. curvatulum, $S$. boyacanum, $S$. fitzgeraldii and $S$. viride. Given the rapid diversification in the genus (Shaw et al. 2010, Stenøien et al. 2010, Shaw et al. 2016), this lack of resolution observed is not surprising.

The newly discovered species can be separated from the other members of Sphagnum Sect. Cuspidata by microstructural differences, as well as the 12 base-pair long insertion event in the rps4 marker unique to the newly discovered Sphagnum. Insertion/deletion mutations (indels) in molecular data sets can provide useful phylogenetic 
information (Kelchner 2000, Graham et al. 2000) and can be of significant value when the rate of base pair substitutions in closely related sequences is fairly low (Ingvarsson et al. 2003). In this case, the insertion appears to be unique not only among the species of the Sphagnum sect. Cuspidata, but among representatives of all the Sphagnopsida.

\section{TAXONOMY}

Sphagnum apopenneysii B.C. Tan, Ignatov, Ignatova \& B. Mishler, spec. nov.

Holotype: Philippines, Mindanao island, Mt. Apo, Lake Jordan, submerged in water, growing beside hummocks formed by Sphagnum junghuhnianum Dozy \& Molk. and $S$. cuspidatum Hoffm. by the shore, May 2, 2014, B.C. Tan \& D.S. Penneys 2014-200. Holotype: UC; isotypes: CAS, CMUH, MW, NY: Figures 2, 3, 4, 5.

[Comment: The label information given above is an exact copy of the handwritten notes of B.C. Tan on his field envelope based on his preliminary field observations (cf. Fig. 1). Note that the single large collection gathered by $\mathrm{Dr}$. Penneys was sorted into morphotypes and sequenced as three distinct entities. Neither the morphological nor molecular studies reported here demonstrated the presence of more than one species in this collection, thus Dr. Tan's initial notation of co-occurrence with Sphagnum junghuhnianum and $S$. cuspidatum has to be considered a mistaken field observation.]

Etymology: The species epithet of the new taxon commemorates the name of the mountain (type locality) and the name of the person, Dr. Darin S. Penneys, who first spotted the plants in Lake Jordan on Mt. Apo.

Description: Plants medium-sized, submerged completely in water, lax, soft, flaccid, with indistinct capitulum; grayish to lightly brownish green, opaque. Stems slender, green, remotely foliate, fascicles of branches around the stem consisting of single or cluster of two, rarely three, slender branches, always spreading; stem and branches in transverse section differentiated into a thin-walled central cylinder, surrounded by 3-4 layers of thick-walled cortical cells and 1-3 layers of hyalodermis; surface or epidermal cells of stem and branches aporose; occasionally epidermal cells of a few branches showing one pore in distal cell end, with an inconspicuous neck, thus, forming an inconspicuous retort cell. Stem leaves erect to erecto-patent, in two sizes, smaller than branch leaves in some plants, while larger than branch leaves in more deeply submerged plants [(1.9-2.2 $\times 0.9-1.2$ $\mathrm{mm}$ in less submerged plants and 7.0-7.4 $\times 1.7-1.9 \mathrm{~mm}$ in more deeply submerged plants], elongate-triangular to lanceolate, entire, slightly serrulate distally; upper half of lamina of stem leaves with homogeneously elongate to vermicular cells, in the middle part of some leaves with slight to moderate differentiation of a net of narrower cells ["weakly differentiated chlorocysts"] alternating with somewhat broader and larger cells ["initial or proto-hyalocysts"], both with green chloroplasts and nucleus [regular median leaf cells $60-120 \mu \mathrm{m}$ long, "weakly differentiated chlorocysts" 9$11 \mu \mathrm{m}$ wide, and "protohyalocysts" 13-18 $\mu \mathrm{m}$ wide]; on some stem leaves the laminal cells exhibit a stronger differentiation towards leaf base, showing the typical Sphagnum-leaf cell dimorphism with the dead hyaline cells being 2-3-times broader than adjacent chlorophyllose cells and possessing a few fibrils, and, more rarely, one pore in the distal end on ventral leaf surface; border cells near the leaf margin of stem leaves not differentiated, consisting of homogeneous cells similar to distal leaf cells; auricles of one or two inflated and thin-walled cells often present at leaf base; in more deeply submerged plants, stem leaves are as long, if not longer than branch leaves, median leaf cells 90-290 $\mu \mathrm{m}$ long, "weakly differentiated chlorocysts" 8-10 $\mu \mathrm{m}$ wide, and "protohyalocysts" 15-18 $\mu \mathrm{m}$ wide. Branch leaves erect to erecto-patent and occasionally slightly falcate-secund, 3.0$3.7 \times 0.9-1.1 \mathrm{~mm}$ [in some deeply submerged plants, $4.8-$ $5.0 \times 0.7-0.8 \mathrm{~mm}$ ], lanceolate to narrow linear-lanceolate, gradually tapered to a narrow, truncate apex, indistinctly concave, weakly serrulate to entire below, slightly toothed at truncate apex; laminal cells monomorphic, distally and proximally slightly differentiated in cell length and width, and in many leaves totally lacking such a weak cellular differentiation, efibrillose. Gametangia and sporophytes unknown.

Variation: The type collection of Sphagnum apopenneysii exhibited a range of variation in leaf size and cell dimensions between plants that were less or more deeply submerged in the lake water. The latter plants tend to have longer leaves, especially stem leaves. The stem leaves of deep-water plants are narrowly lanceolate (Figs. 4A and 4B), while plants growing in more shallow water have ovate-triangular leaves, common for most species of Sphagnum (Figs. 2K$2 \mathrm{M})$. In general, submerged plants of sphagna often form hemi-isophyllous phenotypes, with much elongated stem leaves, which however usually have better expressed cell dimorphism than in stem leaves, e.g., hyalocysts are more strongly fibrillose in this case. In $S$. apopenneysii the plants from deeper water have less developed hyalocysts (cf. Figs. $5 \mathrm{E}$ and $5 \mathrm{~L})$.

\section{CONCLUSION}

We have shown that a combination of morphological and molecular data justifies the description of this new species, which needs further study because of its outstanding morphology. At the same time, it needs the strictest protection. We call it to the attention of conservation organizations and the government of the Philippines, and 
Philippine Journal of Systematic Biology | Tan, B.C. et al: New species of Sphagnum from the Philippines

would urge subsequent researchers to avoid over-collecting this remarkable moss.

\section{ACKNOWLEDGMENTS}

UC Berkeley undergraduate students Dominique Turcotte and Andrew Chen contributed to the molecular study portion of this paper as part of their Undergraduate Research Apprentice Program (URAP) experience in the Mishler Lab. United States National Science Foundation grant DEB1146409 funded a large part of the 2014 expedition to Mindanao along with the California Academy of Sciences Bryophyte Expedition Fund. We are thankful to Darin Penneys for supplying us with his photographs to illustrate the collecting site and plants in situ, as well as exact locality data. Our late colleague Benito $C$. Tan conceived of this study, and wrote the first draft, before his untimely death. We dedicate this paper to him, in fond memory.

\section{LITERATURE CITED}

Allison, K.W., 1963. New and rare mosses in New Zealand. Transactions of the Royal Society of New Zealand, Botany 2: 133-141.

Crum, H.A. \& L.E. Anderson, 1981. Mosses of Eastern North America. Vol. 1. Columbia University press, New York. $663 \mathrm{pp}$.

Eddy, A., 1977. Sphagnales of Tropical Asia. Bulletin of the British Museum (Natural History), Botany, 5: 357-445.

Eddy, A., 1988. A Handbook of Malesian Mosses. Vol. 1. Sphagnales to Dicranales. British Museum (Natural History), London. 204 pp.

Graham, S.W., P.A. Reeves, A.C. Burns \& R.G. Olmstead, 2000. Microstructural changes in noncoding chloroplast DNA: interpretation, evolution, and utility of indels and inversions in basal angiosperm phylogenetic inference. International Journal of Plant Sciences, 161(S6): S83S96.

Griffin III, D.G., 1981. El género Sphagnum en Los Andes de Colombia y Venezuela. Clave para las especies frecuentes u ocasionales con notas ecológicas y taxonómicas. Cryptogamie: Bryologie, Lichénologie, 2: 201-211.

Hanssen, L., S.M. Såstad \& KI. Flatberg, 2000. Population structure and taxonomy of Sphagnum cuspidatum and $S$. viride. The Bryologist, 103: 93-103.

Ingvarsson, P.K., S. Ribstein \& D.R. Taylor, 2003. Molecular evolution of insertions and deletion in the chloroplast genome of Silene. Molecular Biology and Evolution, 20 (11): 1737-1740.

Karlin, E.F., S.B. Boles, R.D. Seppelt, S. Terracciano \& A.J. Shaw, 2011. The peat moss Sphagnum cuspidatum in Australia: microsatellites provide a global perspective. Systematic Botany, 26: 22-32.
Karlin, E.F., W.R. Buck, R.D. Seppelt, S.B. Boles \& A.J. Shaw, 2013. The double allopolyploid Sphagnum $x$ falcatulum (Sphagnaceae) in Tierra del Fuego, a Holantarctic perspective. Journal of Bryology, 35: 157172.

Karlin, E.F. \& S.C. Robinson. 2017. Update on the Holantarctic Sphagnum $\times$ falcatulum s.l. (Sphagnaceae) complex: $S$. irritans is associated with the allo-diploid plants. Journal of Bryology, 39: 8-15.

Kearse, M., R. Moir, A. Wilson, S. Stones-Havas, M. Cheung, S. Sturrock, S. Buxton, A. Cooper, S. Markowitz, C. Duran \& T. Thierer, 2012. Geneious Basic: an integrated and extendable desktop software platform for the organization and analysis of sequence data. Bioinformatics, 28(12): 1647-1649.

Kelchner, S.A., 2000. The evolution of non-coding chloroplast DNA and its application in plant systematics. Annals of the Missouri Botanical Garden: 87(4): 482-498.

Larsson, A., 2014. AliView: a fast and lightweight alignment viewer and editor for large datasets. Bioinformatics, 30 (22): 3276-3278.

Li, X.-J. \& S. He, 1999. Sphagnaceae. In: Cao, C. \& M.R. Crosby, (eds.), Moss Flora of China, English Version. Vol. 1. Sphagnaceae-Leucobryaceae. Science Press (Beijing) and Missouri Botanical Garden (St. Louis). Pp. 3-49.

Nosratinia, S., J.R. Shevock \& B.D. Mishler, 2011. Phylogenetic relationships of Yunnanobryon (Musci: Regmatodontaceae). The Bryologist, 114(3): 547-555.

Nyholm, E., 1969. Illustrated Moss Flora of Fennoscandia II. Musci. Fasc. 6. Gleerups and Swedish Natural Science Council, Lund and Stockholm. Pp. 647-799.

Ochyra, R. \& J. K. Bartlett, 1986. The identity of Drepanocladus fontinaliopsis (C. Muell.) Broth. ex Par. (Bryopsida, Amblystegiaceae). New Zealand Joournal of Botany, 24: 361-368.

Seppelt, R.D., 2006. Sphagnaceae and Ambuchananiaceae. In: McCarthy, P.M., (ed.), Flora of Australia. Vol. 51. Mosses 1. CSIRO Publishing, Canberra. Pp. 89-107.

Sharp, A.J., H. Crum \& P.M. Eckel (eds.), 1994. The moss flora of Mexico. 2 volumes. Memoirs of the New York Botanical Garden, 69: 1-1113.

Shaw, A.J., 2000. Phylogeny of the Sphagnopsida based on chloroplast and nuclear DNA sequences. The Bryologist, 103(2): 277-306.

Shaw, A.J., N. Devos, C.J. Cox, S.B. Boles, B. Shaw, A.M. Buchanan, L. Cave \& R. Seppelt, 2010. Peatmoss (Sphagnum) diversification associated with Miocene Northern Hemisphere climatic cooling? Molecular Phylogenetics and Evolution, 55(3): 1139-1145.

Shaw, A.J. \& B. Goffinet. 2000. Molecular evidence of reticulate evolution in the peat mosses (Sphagnum), including S. ehyalinum sp. nov. The Bryologist, 103: 357374. 
Shaw, A.J., J. Schmutz, N. Devos, S. Shu, A.A. Carrell \& D.J. Weston, 2016. Chapter Five -The Sphagnum Genome Project: A new model for ecological and evolutionary genomics. Advances in Botanical Research, 78: 167-187.

Smith, A.J.E., 1980. The Moss Flora of Britain and Ireland. Cambridge University Press, Cambridge. 706 pp.

Soltis, D.E., E.V. Mavrodiev, J.J. Doyle, J. Rauscher \& P.S. Soltis, 2008. ITS and ETS sequence data and phylogeny reconstruction in allopolyploids and hybrids. Systematic Botany, 33(1): 7-20.

Stamatakis, A., 2006. RAxML-VI-HPC: maximum likelihoodbased phylogenetic analyses with thousands of taxa and mixed models. Bioinformatics, 22(21): 2688-2690.

Stamatakis, A., P. Hoover \& J. Rougemont, 2008. A rapid bootstrap algorithm for the RAxML web servers. Systematic Biology, 57(5): 758-771.

Stenøien, H.K., A.J. Shaw, B. Shaw, K. Hassel \& U. Gunnarsson, 2011. North American origin and recent European establishments of the amphi-atlantic peat moss Sphagnum angermanicum. Evolution, 65(4): 1181-1194.

Taberlet, P., L. Gielly, G. Pautou \& J. Bouvet, 1991. Universal primers for amplification of three non-coding regions of chloroplast DNA. Plant Molecular Biology, 17(5): 11051109.

Tan, B.C. \& Z. Iwatsuki, 1991. A new annotated Philippine moss checklist. Harvard Papers in Botany 3: 1-64.

Urbatsch, L.E., B.G. Baldwin \& M.J. Donoghue, 2000. Phylogeny of the coneflowers and relatives (Heliantheae: Asteraceae) based on nuclear rDNA internal transcribed spacer (ITS) sequences and chloroplast DNA restriction site data. Systematic Botany, 25(3): 539-565.

Warnstorf, C., 1893. Beiträg zur Kenntis exotischer Sphagna. Hedwigia, 32: 1-17.

White, T.J., T. Bruns, S.J.W.T. Lee \& J.L. Taylor, 1990. Amplification and direct sequencing of fungal ribosomal RNA genes for phylogenetics. PCR Protocols: A Guide to Methods and Applications, 18(1): 315-322.

Willis, J. H. 1953. Systematic notes on Victorian mosses -2 . Sphagnum. Victorian Naturalist, 70: 55-57. 